\title{
Well-Based Quantitative Reservoir Characterization of Eocene Sokor-1 Formation, Termit Basin, Niger
}

\author{
Hassane Amadou ${ }^{1,2^{*}}$, Chukwuemeka Ngozi Ehirim ${ }^{3}$, Tamunonengiyeofori Dagogo ${ }^{3}$ \\ ${ }^{1}$ The World Bank, ACE-CEFOR, University of Port Harcourt, Choba, Port Harcourt, Rivers State, Nigeria \\ ${ }^{2}$ Ministère du Pétrole, Immeuble Ex-ONAREM, BP: 11700, Niamey, République du Niger \\ ${ }^{3}$ Physics Department Uniport of Port Harcourt, Choba, Port Harcourt, Rivers State, Nigeria \\ Email: *amabark@yahoo.com
}

How to cite this paper: Amadou, H., Ehirim, C.N. and Dagogo, T. (2021) Well-Based Quantitative Reservoir Characterization of Eocene Sokor-1 Formation, Termit Basin, Niger. International Journal of Geosciences, 12, 159-169.

https://doi.org/10.4236/ijg.2021.122010

Received: January 25, 2021

Accepted: February 23, 2021

Published: February 26, 2021

Copyright $\odot 2021$ by author(s) and Scientific Research Publishing Inc. This work is licensed under the Creative Commons Attribution International License (CC BY 4.0).

http://creativecommons.org/licenses/by/4.0/

\begin{abstract}
The Eocene Sokorl Formation is proven oil reservoir rocks in the Termit sub-basin. These sandstone intervals are deeply buried, highly heterogeneous in character and characterized by Low Contrast Low Resistivity (LCLR) log responses. Petrophysical and quantitative well-based rock physics interpretations were integrated for property estimations, fluid and lithology typing in reservoir characterization. Six (6) reservoir sandstone intervals were identified, delineated and correlated across five (5) wells. The estimated petrophysical properties showed that the Eocene Sokorl sandstones have averagely good reservoir properties with sand_5 interval exhibiting exceptional reservoir properties. $V_{p} / V_{s}$ vs. AI and $\mu \rho$ vs. $\lambda \rho$ elastic cross-plots color coded with reservoir properties $\left(V_{s h}\right.$ and $\phi$ ), show distinct and well separated data clusters signifying hydrocarbon bearing sandstones, brine sandstones and shales/mudstones in the 3D crossplot planes with varying seismic elastic property values in each well thereby, enhancing reservoir characterization and providing information's about the burial history, reservoir quality and property distribution in the sub-basin. The analysis suggests that, although the reservoir interval has averagely good petrophysical properties in all wells, the seismic elastic crossplots show that these properties are much better distributed in wells 2 and 3 than in wells 4,5 and 9. Therefore, sand_5 reservoir interval in wells 2 and 3 is likely to be more hydrocarbon bearing and productive than wells 4, 5 and 9 in the sub-basin.
\end{abstract}

\section{Keywords}

Petrophysics, LCLR Reservoirs, Elastic Properties, Crossplots, Termit Sub-Basin 


\section{Introduction}

Hydrocarbon reservoir rocks are distinguished based on their quality and exceptional petrophysical (reservoir) properties. The quality of the reservoir is dependent on the rock type, environment of deposition and burial history, which determines their specific character and properties. Reservoir properties such as lithology, porosity, clay volume, grain size, fluid saturation, permeability among many others, are essential for the characterization of hydrocarbon reservoirs. Although, these properties are easily derived from core analysis, they can also be estimated through petrophysical evaluation from well log measurements.

However, the ability to adequately characterize hydrocarbon reservoirs with complex sedimentary properties and heterogeneities from well logs remains a great challenge. These types of reservoirs exhibit Low Contrast Low Resistivity (LCLR) log responses. Discriminating reservoir sands from shales and hydrocarbon sands from brine sands as well as accurately evaluating the distribution of relevant reservoir properties are complicated and tasking in LCLR reservoirs from petrophysics alone.

Seismic elastic properties are very useful in identifying lithology and pore fluids, predicting reservoir properties and for mineral identification [1] [2]. The crossplot of appropriate pairs of elastic properties color-coded with relevant reservoir properties in 3D crossplot domain can effectively discriminate lithologies and characterizes pore fluids by their distinct and separate clusters, allowing for straightforward interpretations and characterizations [3] [4]. Therefore, integrating petrophysics with quantitative well-based elastic crossplots will ensure that LCLR reservoirs are adequately characterized.

Termit sub-basin is situated within the Chad Basin in Niger (Figure 1). The basin is hydrocarbon bearing with the major finds located in the upper

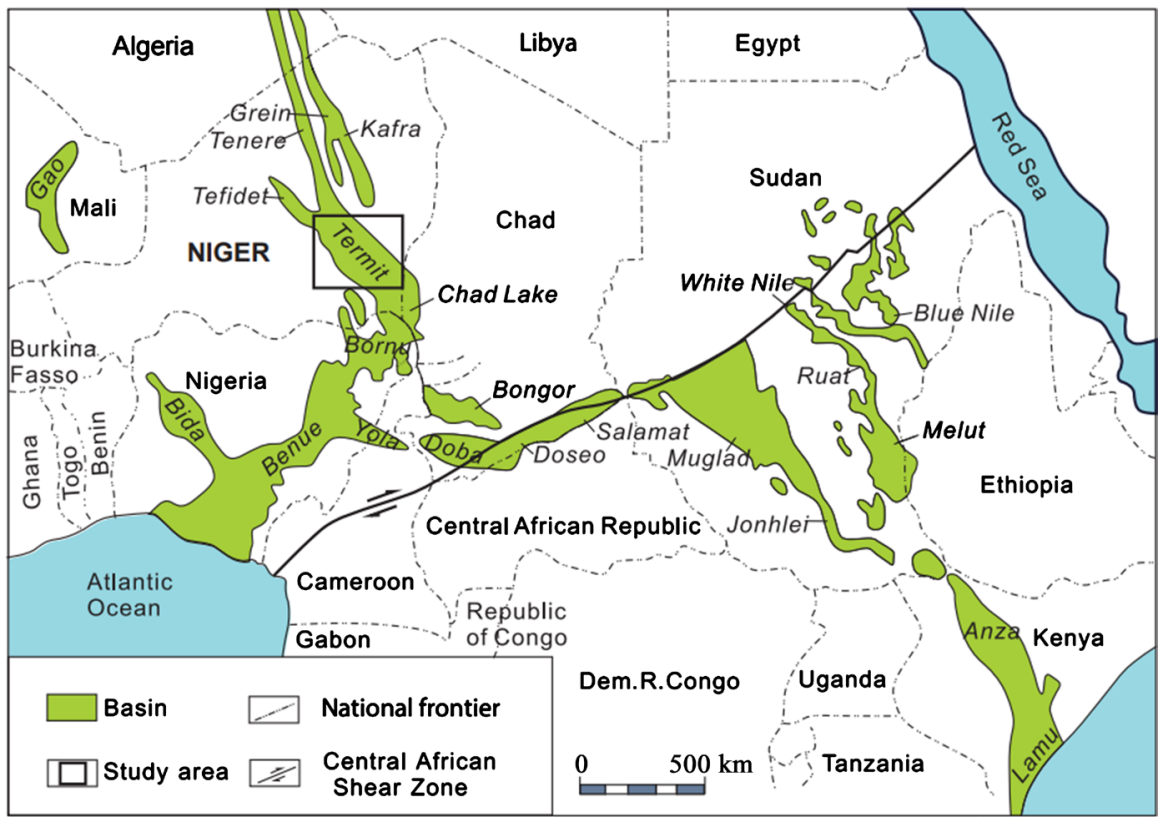

Figure 1. Location of the study area [5] [6]. 
cretaceous to Paleocene-Eocene sandstones. Tectonic activities controlled sedimentary processes, making the reservoirs in most cases complex and heterogeneous typical of LCLR reservoirs.

Several authors [7] [8] [9] [10] [11], have adopted different approaches to estimate petrophysical properties and their distribution from well log data in LCLR reservoirs in Termit sub-basin. Similarly, [12] [13] [14] [15] [16], have proposed different techniques for fluid and lithology discrimination in reservoir characterizations.

The goal of the present study in the midst of all these challenges is to improve petrophysical reservoir properties prediction as well as discriminate lithologies and characterize pore fluids through the integration of petrophysics with quantitative well-based seismic elastic property crossplots in $3 \mathrm{D}$ crossplot space to adequately and efficiently characterize LCLR Sokor1 reservoir formation.

\section{Geology of the Study Area}

Termit sub-basin is an extensional asymmetric Cretaceous-Tertiary rift system, $575 \mathrm{~km}$ long and 150 - $300 \mathrm{~km}$ wide. It is filled with Lower Cretaceous to Neogene sedimentary rocks, deposited in fluvial, lacustrine, and marine environments and ranging in thickness from about $3000 \mathrm{~m}$ to more than 12,000 $\mathrm{m}$ [5] [6] [17] [18] [19] [20].

The sub-basin consists of Donga, Yogou, and Madama Formations in the Upper Cretaceous, Sokor1 in the Paleocene-Eocene and Sokor2 in the Oligocene (Figure 2). The Paleocene-Eocene Sokor1 Formation, which is the major oil producing reservoirs in the area, has sandstones interbedded with mudstone/shale deposits. The sandstones are divided into six (6) sand groups: E0, E1, E2, E3, E4 and E5. The Sokor2 formation is mainly composed of lacustrine mudstone interbedded by thin sandstone layers [21]. Sokor1 - Sokor2 is identified as a petroleum system with the Sokor1 sandstones as the reservoirs and Sokor2 mudstones/shales acting as the regional seal. These formations are penetrated and dissected by northwest-southeast (NW-SE) synthetic and north-northwest south-southeast (NNW-SSE) antithetic normal faults, respectively, and northeast-southwest (NE-SW) transpressional anticlines forming the necessary and required structural traps for hydrocarbon accumulation in the sub-basin [18] [21].

\section{Method of Study}

Five wells (5) namely wells 2, 3, 4, 5 and 9 comprising of suit of well logs such as Gamma ray (GR), resistivity (RT), neutron (NPHI), density (RHOB) and sonic logs were used in the present study. After quality control and editing, gamma ray and resistivity logs as well as neutron-density crossovers were used to discriminate lithologies, map reservoir intervals and characterize pore fluids. The reservoirs were further correlated for purposes of continuity and lateral extension across wells in the field. 


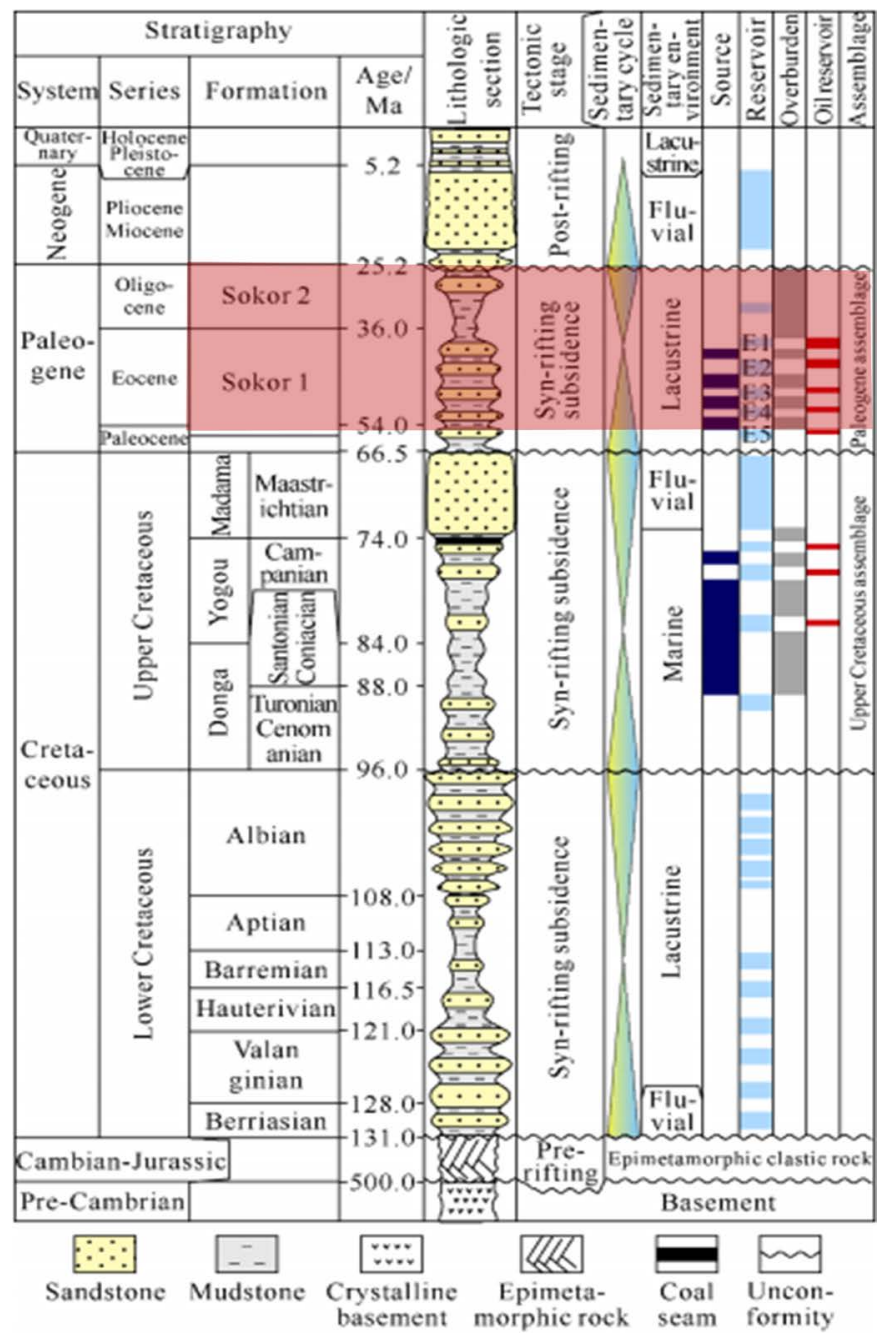

Figure 2. Composite stratigraphic column of the Termit Basin [17].

Petrophysical evaluation was carried out to estimate petrophysical reservoir properties such as porosity $(\phi)$, volume of shale $\left(V_{s h}\right)$, water saturation $\left(S_{W}\right)$, hydrocarbon saturation $\left(S_{h c}\right)$ and reservoir thickness $(\mathrm{t})$ using well established petrophysical model equations [22].

Shear wave velocity $\left(V_{s}\right)$ was estimated from the measured compressional velocity $\left(V_{p}\right)$ using Greenberg and Castagna (1992) relation [23]. Subsequently, seismic elastic logs such as compressional to shear wave velocity ration $\left(V_{p} / V_{s}\right)$, compressional acoustic impedance (P-Imp/AI), shear acoustic impedance (S-Imp), volume of shale $\left(V_{s h}\right)$, water saturation $\left(S_{w}\right)$, porosity (Por), lambda-rho $(\lambda \rho)$ and mu-rho $(\mu \rho)$ were computed for the wells through petrophysical rock physics transforms using Hampson-Russell (HR) software suit (Figure 3). Due to the effects of reservoir heterogeneity resulting in LCLR reservoirs, quantitative well-based elastic property crossplots ( $V_{p} / V_{s}$ vs. AI and $\mu \rho$ vs. $\lambda \rho$ ) color coded with relevant reservoir properties such as $V_{s h}$ and $\phi$, were performed in $3 \mathrm{D}$ domain to further discriminate lithologies and characterize pore fluids for the reservoir intervals in each well. 


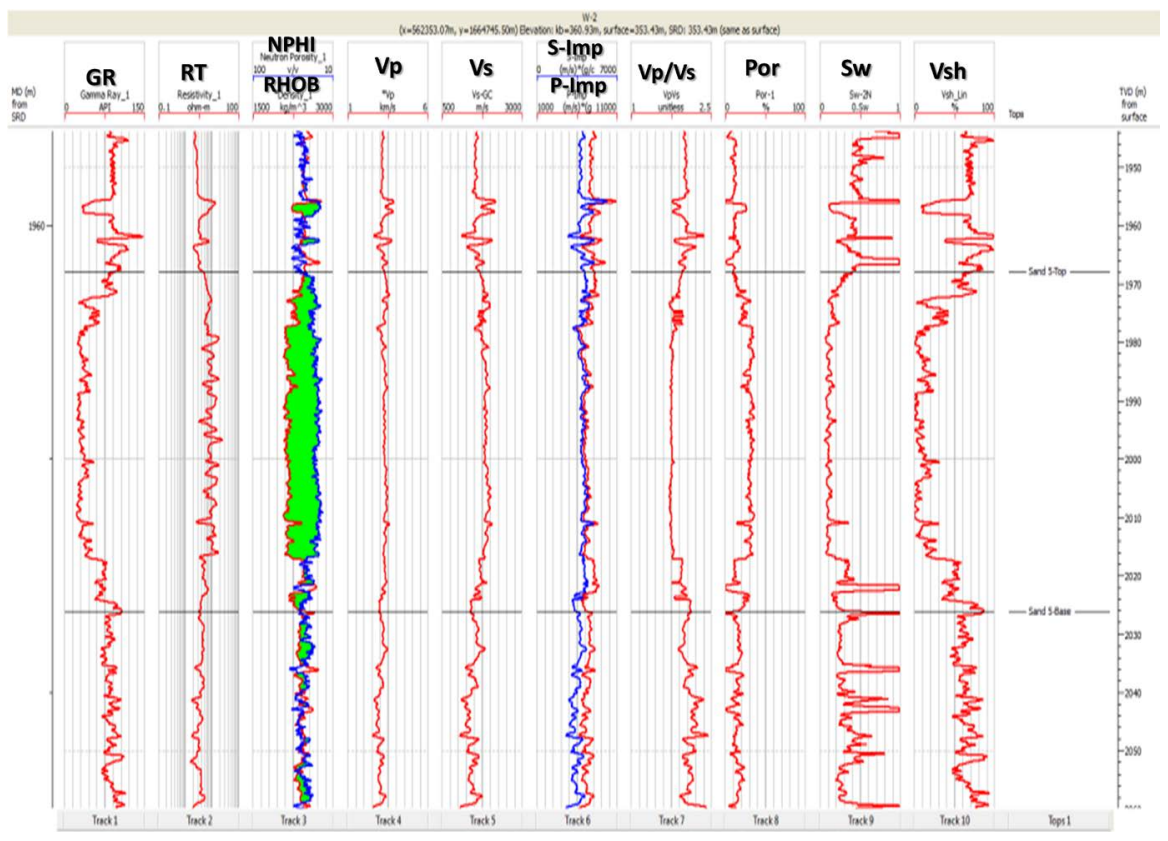

Figure 3. Typical well and seismic elastic logs for well 2 (sand_5 reservoir interval).

\section{Results Presentation}

Reservoir rocks (shale/mudstone and sand) and pore fluids were discriminated and characterized by poor property contrast in the log responses. Lithology is mainly alternating beds of sandstone and shale/mudstone along the well bore, characteristics of the Eocene Sokor1 Formation in Termit sub-basin. Six (6) hydrocarbon sandstone reservoirs were delineated by moderate GR and low resistivity log responses with fairly large density-neutron crossover typical of LCLR reservoirs. Shales (mudstones) beds were delineated by moderate to high GR log response. The well-to-well correlation identified and mapped the sand intervals across wells (Figure 4). The correlated sandstone intervals were continuous and vary in thicknesses and depths from well to well, which could be associated with the tectonics of the area.

Petrophysical analyses of the six (6) reservoirs intervals suggest fairly good petrophysical reservoir properties. Result suggests that sand_5 reservoir interval has the best petrophysical reservoir properties (Table 1), with estimated thickness, porosity, volume of shale, water saturation, and hydrocarbon saturation values of $61.0 \mathrm{~m}, 24.4 \%, 16.4 \%, 16.6 \%$ and $83.4 \%$, respectively. In view of these petrophysical results, sand_5 reservoir interval was adopted for further quantitative analysis and interpretation in this study.

Well-based seismic elastic property crossplots of $V_{P} / V_{s}$ vs. AI and $\mu \rho$ vs. $\lambda \rho$ color coded with $V_{s h}$ and $\phi$ respectively, are shown in Figures 5-7 alongside gamma ray and resistivity log sections of the analyzed interval. Results show distinct and well separated data clusters signifying hydrocarbon bearing sandstones, brine sandstones and shales/mudstones in the 3D crossplot planes.

$V_{p} / V_{s}$ vs. AI crossplot color coded with $V_{s h}$ and $\phi$, respectively (Figure 5 and 


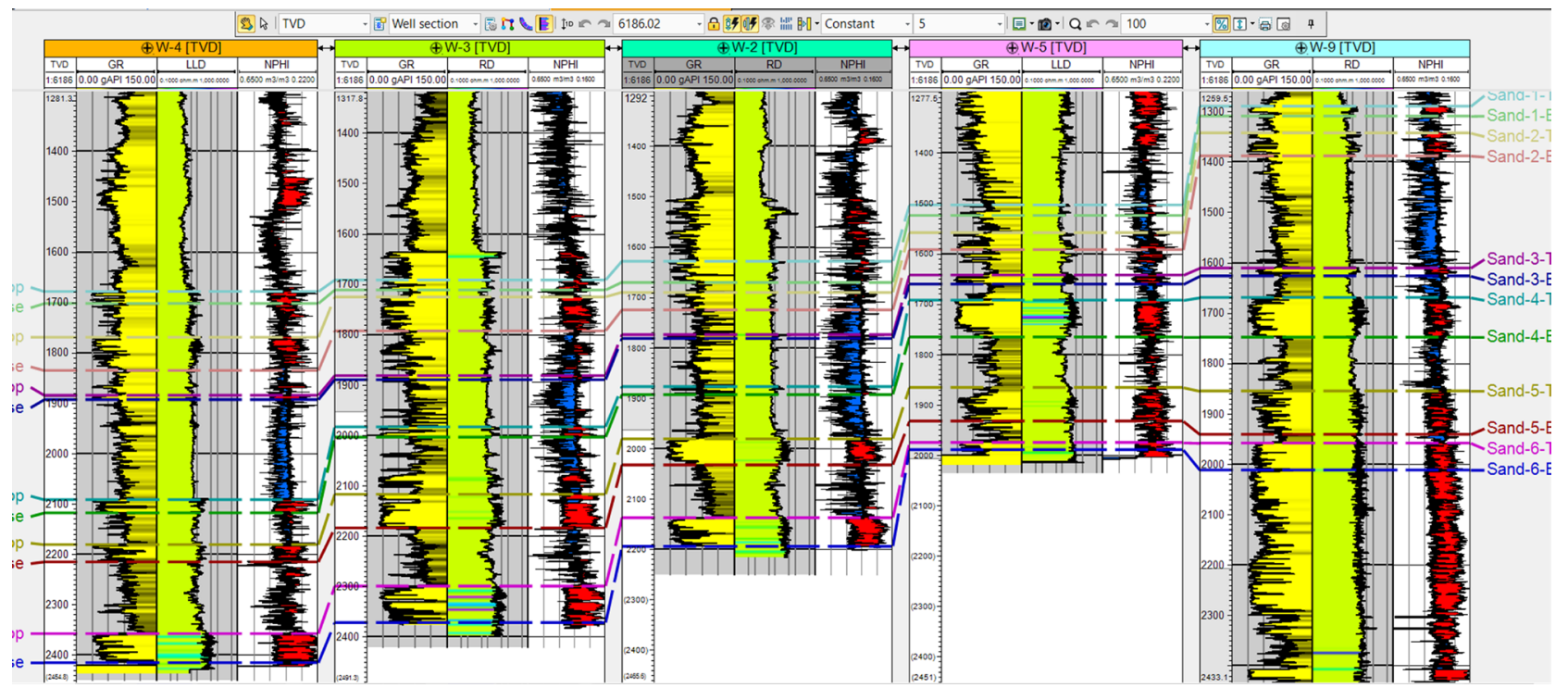

Figure 4. Correlation panel across wells for the reservoir intervals.

Table 1. Summary of the petrophysical properties of delineated sands.

\begin{tabular}{cccccc}
\hline RESERVOIRS & THICKNESS $(\mathrm{m})$ & POROSITY $\%$ & SHALE VOL. $\%$ & $S_{w} \%$ & $S_{h c} \%$ \\
\hline 1 & 25.0 & 29.7 & 17.8 & 22.6 & 77.4 \\
2 & 49.0 & 24.8 & 31.4 & 24 & 76.0 \\
3 & 12.0 & 24.8 & 29.6 & 22 & 78.0 \\
4 & 39.0 & 22.6 & 31.2 & 23.8 & 76.2 \\
5 & 61.0 & 24.4 & 16.4 & 16.6 & 83.4 \\
6 & 52.0 & 22.8 & 15.6 & 15 & 85.0 \\
\hline
\end{tabular}
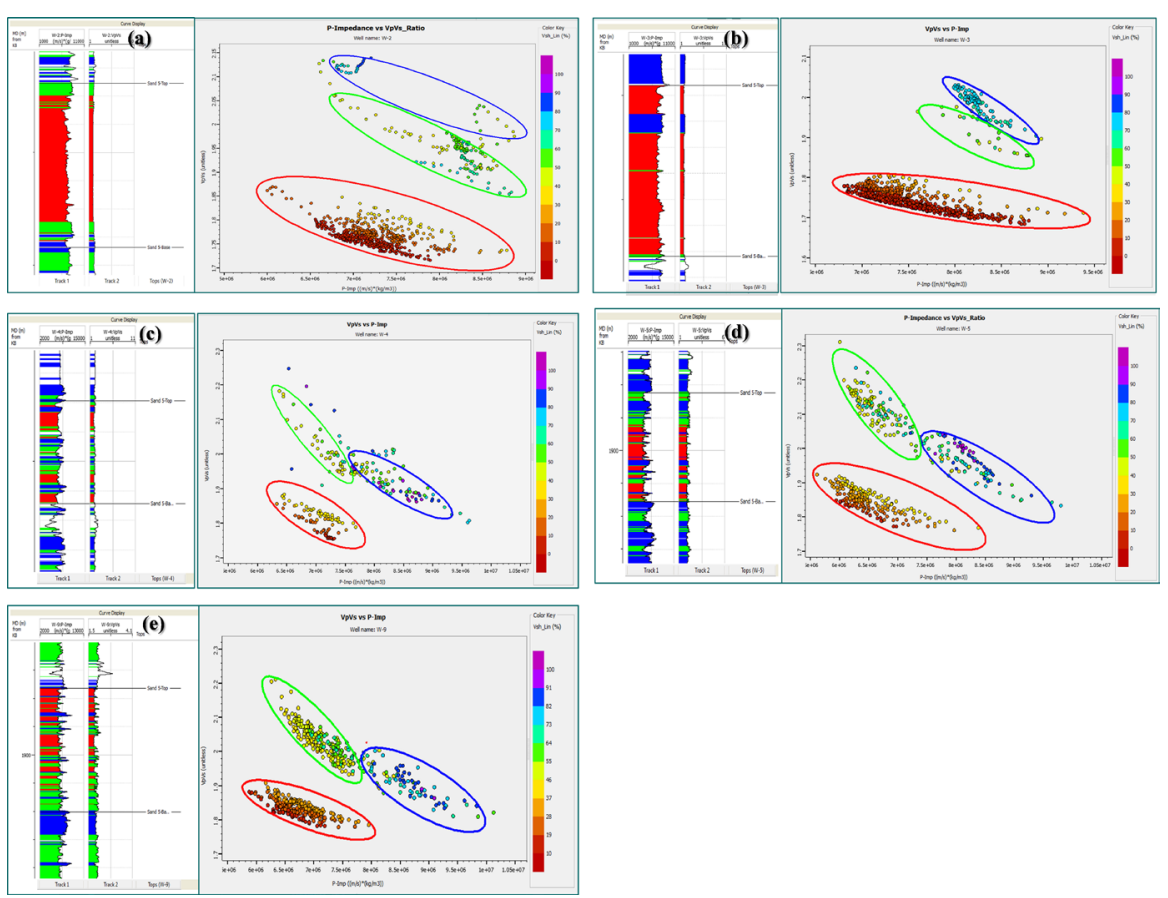

Figure 5. Cross-plots of $V_{p} / V_{s}$ vs. AI color code with $V_{\text {sh: }}$ (a) Well-2; (b) Well-3; (c) Well-4; (d) Well-5 and (e) Well-9. 


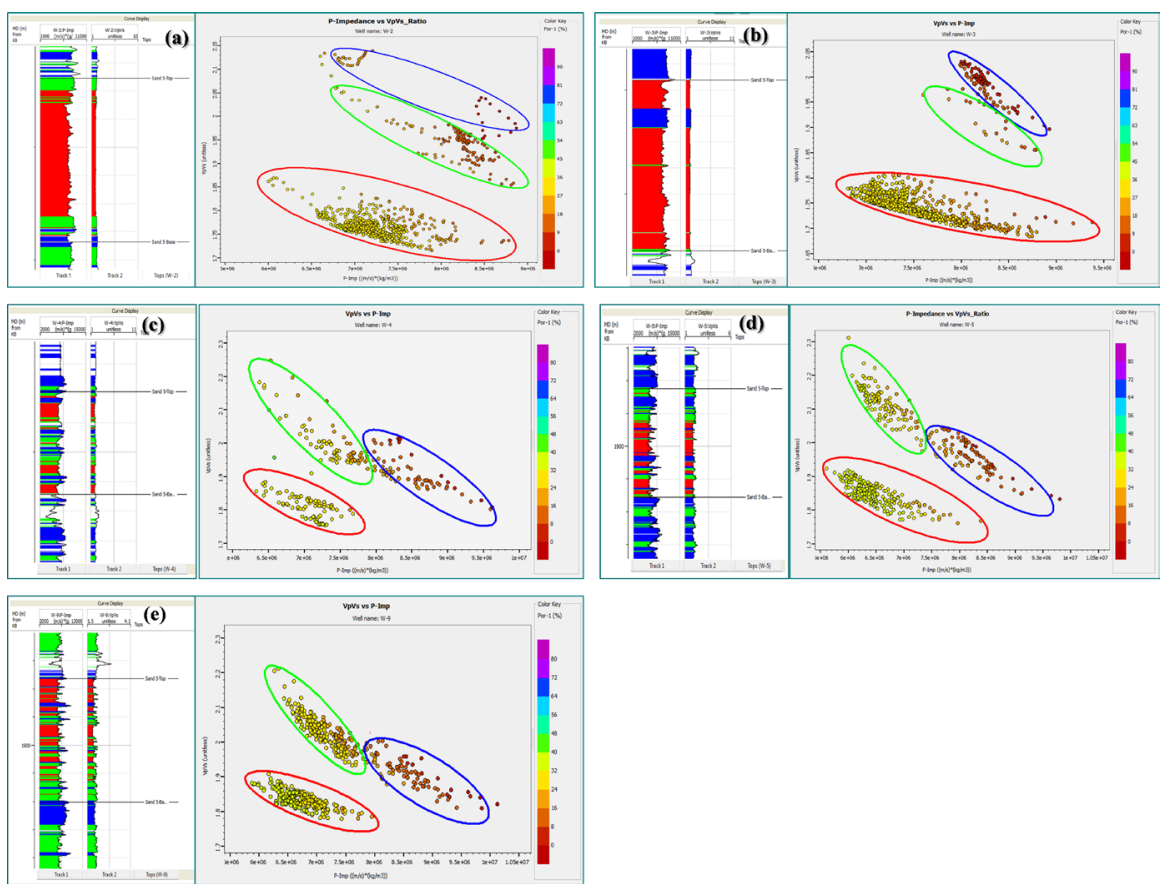

Figure 6. Cross-plots of $V_{p} / V_{s}$ vs. AI color code with $\phi$ : (a) Well-2; (b) Well-3; (c) Well-4; (d) Well-5 and (e) Well-9.

Figure 6), show that hydrocarbon saturated sands (red ellipse) depict low $V_{p} / V_{s}$ and high AI in wells 2 and 3 and low $V_{p} / V_{s}$ and moderate AI in wells 4, 5 and 9 respectively, corresponding to low $V_{s h}$ and high $\phi$. The brine sandstones plot as high $V_{p} / V_{s}$ but moderate AI (green ellipse) while shales/mudstones plot as high $V_{p} / V_{s}$ and high AI (blue ellipse) in all the wells, corresponding to high $V_{s h}$ and low $\phi$ values [12] [24] [25].

In the $\mu \rho$ vs. $\lambda \rho$ crossplot color coded with $V_{s h}$ only (Figure 7), hydrocarbon saturated sands (red ellipse) depict high $\mu \rho$ and low $\lambda \rho$ in wells 2 and 3, and low $\mu \rho$ and $\lambda \rho$ in wells 4, 5 and 9, respectively, with to low $V_{s h}$. Brine sands (green ellipse) plot as moderate $\mu \rho$ and $\lambda \rho$ in all the wells, while shales/mudstones (blue ellipse) plot as low $\mu \rho$ and high $\lambda \rho$ in wells 2 and 3, but high $\mu \rho$ and $\lambda \rho$ in wells 4 , 5 and 9, respectively, with high $V_{s h}$ [12] [24] [25].

The present study has shown that $\mu \rho$ vs. $\lambda \rho$ crossplots clearly separates the data clusters into their distinct litho-fluid parts than the $V_{p} / V_{s}$ vs. AI crossplot pairs and petrophysics for typical LCLR reservoirs. Result show that wells 2 and 3 have high seismic elastic property values within the hydrocarbon bearing intervals than wells 4,5 and 9 in each of the crossplot property pairs. These could be attributed to varying degrees of consolidation and cementation in each well due to differences in burial depths.

\section{Discussion of Results}

Petrophysical analysis delineated six (6) sandstone reservoir intervals by moderate GR and low resistivity log responses with fairly large neutron-density crossovers. Shales/mudstones were identified and mapped by high GR log 


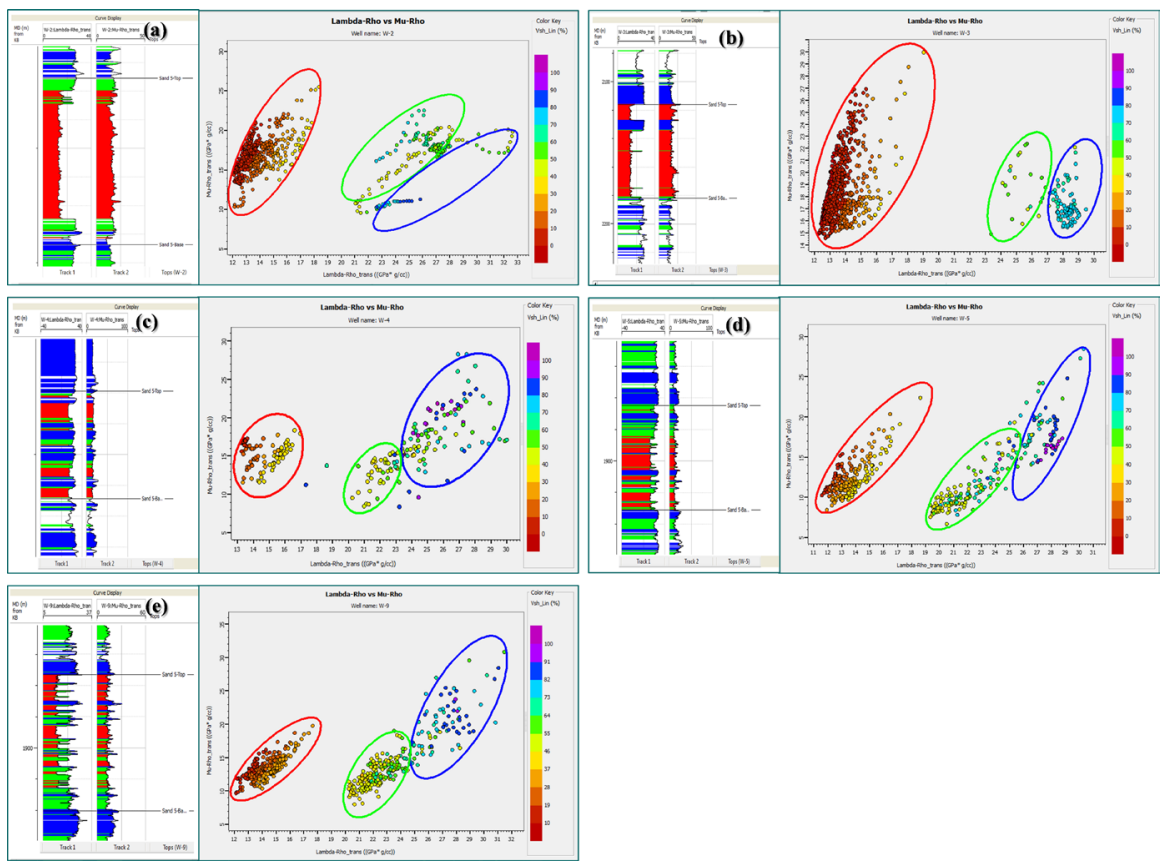

Figure 7. Cross-plots of $\mu \rho$ vs. $\lambda \rho$ color coded with $V_{s h}$ : (a) Well-2; (b) Well-3; (c) Well-4; (d) Well-5 and (e) Well-9.

response. The LCLR characteristic of the hydrocarbon reservoirs is attributed to clay minerals containing high concentration of radioactive materials within the reservoir intervals [10]. The correlated wells mapped reservoir sandstones continuously with varying thicknesses and depths across wells. This suggests faulting and uplift associated with tectonics that has considerably impacted sedimentary processes, hydrocarbon generation and maturation in the sub-basin.

Petrophysical analyses of the six (6) reservoir intervals also indicate that each reservoir has good potential for hydrocarbons with fairly good petrophysical reservoir properties. However, sand_5 reservoir interval has the best petrophysical reservoir properties with estimated thickness, porosity, volume of shale, water saturation, and hydrocarbon saturation values of $61.0 \mathrm{~m}, 24.4 \%, 16.4 \%, 16.6 \%$ and $83.4 \%$, respectively. Subsequently, this was adopted for further quantitative analysis and interpretation in this study.

The cross-plots of $V_{p} / V_{s}$ vs. AI and $\mu \rho$ vs. $\lambda \rho$ color coded with $V_{s h}$ and $\phi$, respectively, delineated hydrocarbon saturated sandstones by low $V_{p} / V_{s}$ and $\lambda \rho$ and high AI and $\mu \rho$ in wells 2 and 3 and by low $V_{p} / V_{s}, \lambda \rho$ and $\mu \rho$ and moderately high AI in wells 4, 5 and 9 corresponding to low $V_{s h}$ and high $\phi$ values. The brine sandstones plot as high $V_{p} / V_{s}$ but with moderate AI, $\mu \rho$ and $\lambda \rho$ in all the wells. The shales/mudstones plot as high $V_{p} / V_{s}$, AI and $\lambda \rho$ and low $\mu \rho$ in wells 2 and 3 but with moderate $V_{p} / V_{s}$ and high $\mu \rho, \lambda \rho$ and AI in wells 4, 5 and 9 , respectively. The reservoir properties vary greatly in the hydrocarbon intervals, with wells 2 and 3 for instance, having lower reservoir porosities than wells 4,5 and 9 . This is probably due to increasing clay content, cementation and consolidation of the reservoir interval with depth [2] [26] [27]. 
Result of the present analysis show that wells 2 and 3 are characterized by high seismic elastic property values ( $\mathrm{AI}$ and $\mu \rho$ ) within the hydrocarbon bearing sandstone intervals than wells 4,5 and 9 in each case of the crossplot property pairs. The low $V_{p} / V_{s}$ and $\lambda \rho$ and high $\mathrm{AI}$ and $\mu \rho$ values in wells 2 and 3 suggests a cemented and consolidated hydrocarbon reservoir sandstones, while the low $V_{p} / V_{s}, \lambda \rho$ and abnormally low $\mu \rho$ and moderately high AI values in wells 4,5 and 9 suggests an unconsolidated but cemented hydrocarbon reservoirs sandstone [12] [16] [28] [29].

In view of the above, sand_5 reservoir interval in wells 2 and 3 are more likely to be hydrocarbon bearing and productive than wells 4,5 and 9 in the sub-basin. The low $\mu \rho$ in wells 2 and 3 suggests that the shales/mudstones are unconsolidated and soft than the consolidated and hard shales/mudstones in wells 4, 5 and 9 with high $\mu \rho$ values. These variations in texture will affect the sealing capacity of the shales/mudstones in the reservoir interval for each the well.

\section{Conclusion}

Petrophysical evaluation of LCLR sand_5 reservoir interval in Eocene Sokor1 Formation suffers from the limitations of accurately discriminating reservoir sands from shales and hydrocarbon sands from brine sands posed by reservoir heterogeneity. This has affected reservoir characterization and estimation of the distribution of relevant reservoir properties in the well bore. However, quantitative well-based crossplots of seismic elastic properties have effectively discriminated the reservoir interval into lithology and pore fluid components by their distinct and separate clusters in 3D space thereby, enhancing reservoir characterization and providing information's about the burial history, reservoir quality and property distribution in the sub-basin. The analysis suggests that, although the reservoir interval has averagely good petrophysical properties in all wells, the properties are much better in wells 2 and 3 than in wells 4,5 and 9. Results suggest that sand_5 reservoir sandstones in wells 2 and 3 are cemented and consolidated, whereas there are cemented but unconsolidated in wells 4, 5 and 9 based on the variations in elastic property values in the wells. Therefore, sand_5 reservoir interval in wells 2 and 3 is more likely to be hydrocarbon bearing and productive than wells 4,5 and 9 in the sub-basin.

\section{Acknowledgements}

We would like to thank The Ministry of Petroleum (MPe), Niger Republic, for providing the data for this study, and for permission to publish this work. Our thanks also go to World Bank African Centre of Excellence, Centre for Oilfield Chemical Research (ACE-CEFOR), University of Port Harcourt (UNIPORT), for giving me the opportunity to conduct this research.

\section{Conflicts of Interest}

The authors declare no conflicts of interest regarding the publication of this paper. 


\section{References}

[1] Ødegaard, E. and Avseth, P. (2004) Well Log and Seismic Data Analysis Using Rock Physics Templates. First Break, 22, 37-43.

https://doi.org/10.3997/1365-2397.2004017

[2] Avseth, P., Mukerji, T., Mavko, G. and Dvorkin, J. (2010) Rock Physics Diagnostics of Depositional Texture, Diagenetic Alterations, and Reservoir Heterogeneity in Highporosity Siliciclastic Sediments and Rocks-A Review of Selected Models and Suggested Workflows. Geophysics, 75, A31-A47. https://doi.org/10.1190/1.3483770

[3] Hamada, G.M. (2004) Reservoir Fluids Identification Using $V p / V s$ Ratio: Oil \& Gas Science and Technology. Oil \& Gas Science and Technology-Revue De L Institut Francais Du Petrole, 59, 649-654. https://doi.org/10.2516/ogst:2004046

[4] Chopra, S., Castagna, J. and Portniaguine, O. (2006) Thin-Bed Reflectivity Inversion. SEG Technical Program Expanded Abstracts, 25, 2057-2061.

https://doi.org/10.1190/1.2369941

[5] Genik, G.J. (1993) Petroleum Geology of Cretaceous-Tertiary Rifts Basins in Niger, Chad and Central African Republic. American Association of Petroleum Geologists Bulletin, 73, 153-168.

[6] Harouna, M. and Philp, R.P. (2012) Potential Petroleum Source Rocks in the Termit Basin, Niger. Journal of Petroleum Geology, 35, 165-186.

https://doi.org/10.1111/j.1747-5457.2012.00524.x

[7] Nasaruddin, M.N., Zung, L.S. and Rafek, A.G.M. (2017) Petrophysical Analysis of E5 Sand Group of Sokor Formation, Termit Basin, Niger. IOP Conference Series. Earth and Environmental Science, 88, Article ID: 012003. https://doi.org/10.1088/1755-1315/88/1/012003

[8] Chang, E. and Zung, L.S. (2017) 3D Reservoir Characterization of Field Deta, Termit Basin, Niger. In: Awang, M., et al., Eds., Proceedings of the International Conference on Integrated Petroleum Engineering and Geosciences, Springer, Berlin, 323-335. https://doi.org/10.1007/978-981-10-3650-7 28

[9] Zhao, N., Gao, X., Huang, J., Chen, Z. and Zhang, G. (2018) Sedimentary Characteristics and Lithological Trap Identification of Distant Braided Delta Deposits: A Case on Upper Cretaceous Yogou Formation of Termit Basin, Niger. E3S Web of Conferences, 53, Article ID: 03020. https://doi.org/10.1051/e3sconf/20185303020

[10] Eevon, C. and Lo, S.Z. (2016) 3D Reservoir Characterization of Field Deta, Termit Basin, Niger. In: Proceedings of the International Conference on Integrated Petroleum Engineering and Geosciences, Springer, Berlin, 323-335. https://doi.org/10.1007/978-981-10-3650-7 28

[11] Lai, H., Li, M., Mao, F., Liu, J., Xiao, H., Tang, Y. and Shi, S. (2020) Source Rock Types, Distribution and Their Hydrocarbon Generative Potential within the Paleogene Sokor-1 and LV Formations in Termit Basin, Niger. Energy Exploration \& EXploitation, 38, 2143-2168. https://doi.org/10.1177/0144598720915534

[12] Castagna, J.P. and Swan, H.W. (1997) Principles of AVO Cross-Plotting. The Leading Edge, 17, 337-342. https://doi.org/10.1190/1.1437626

[13] Chi, X.G. and Han, D.H. (2009) Lithology and Fluid Differentiation Using a Rock Physics Template. The Leading Edge, 28, 60-65. https://doi.org/10.1190/1.3064147

[14] Hu, R.Y., Holden, T. and Broussard, M. (2011) Petrophysics and Rock Physics Modeling to Improve Seismic Reservoir Characterization-Case Study of Lower Hackberry Sandstone. AAPG Annual Convention and Exhibition, Houston, 10-13 April 2011, Article \# 40774 . 
[15] Ahmed, N., Khalid, P. and Anwar, A.W. (2016) Rock Physics Modeling to Assess the Impact of Spatial Distribution Pattern of Pore Fluid and Clay Contents on Acoustic Signatures of Partially-Saturated Reservoirs. Acta Geodaetica et Geophysica, 51, 1-13. https://doi.org/10.1007/s40328-015-0101-0

[16] Azeem, T., Chun, W.Y., Lisa, M., Khalid, P., Qing, L.X., Ehsan, M.I., Munawar, M.J. and Wei, X. (2017) An Integrated Petrophysical and Rock Physics Analysis to Improve Reservoir Characterization of Cretaceous Sand Intervals in Middle Indus Basin, Pakistan. Journal of Geophysics and Engineering, 14, 212-225. https://doi.org/10.1088/1742-2140/14/2/212

[17] Zhou, L., Su, J., Dong, X., Shi, B., Sun, Z., Qian, M., Lou, D. and Liu, A. (2017) Controlling Factors of Hydrocarbon Accumulation in Termit Rift Superimposed Basin, Niger. Petroleum Exploration and Development, 44, 358-367. https://doi.org/10.1016/S1876-3804(17)30042-3

[18] Genik, G.J. (1992) Regional Framework, Structural and Petroleum Aspects of Rift Basins in Niger, Chad and the Central African Republic (C.A.R.). Tectonophysics, 213, 169-185. https://doi.org/10.1016/B978-0-444-89912-5.50036-3

[19] Zanguina, M., Bruneton, A. and Gonnard, R. (1998) An Introduction to the Petroleum Potential of Niger. Journal of Petroleum Geology, 2, 83-103. https://doi.org/10.1111/j.1747-5457.1998.tb00647.x

[20] Liu, B., Wan, L., Mao, F., Liu, J., Lü, M. and Wang, Y. (2015) Hydrocarbon Potential of Upper Cretaceous Marine Source Rocks in the Termit Basin, Niger. Journal of Petroleum Geology, 38, 157-175. https://doi.org/10.1111/jpg.12604

[21] Wan, L., Liu, J., Mao, F., L, M. and Liu, B. (2014) The Petroleum Geochemistry of the Termit Basin, Eastern Niger. Marine and Petroleum Geology, 51, 167-183. https://doi.org/10.1016/j.marpetgeo.2013.11.006

[22] Asquith, G. and Gibson, C. (1982) Basic Well Log Analysis for Geologists. Methods in Exploration Series. American Association of Petroleum Geologists, Tulsa.

[23] Greenberg, M.L. and Castagna, J.P. (1992) Shear-Wave Velocity Estimation in Porous Rocks: Theoretical Formulation, Preliminary Verification and Applications. Geophysical Prospecting, 40, 195-209. https://doi.org/10.1111/j.1365-2478.1992.tb00371.x

[24] Castagna, J.P. and Backus, M.M. (1993) Offset-Dependent Reflectivity-Theory and Practice of AVO Analysis. SEG Investigations in Geophysics No. 8.

https://doi.org/10.1190/1.9781560802624

[25] Avseth, P., Mukerji, T. and Mavko, G. (2005) Quantitative Seismic Interpretation: Applying Rock Physics Tools to Reduce Interpretation Risk. Cambridge University Press, Cambridge. https://doi.org/10.1017/CBO9780511600074

[26] Avseth, P., Dvorkin, J., Mavko, G. and Rykkje, J. (2000) Rock Physics Diagnostic of North Sea Sands: Link between Microstructure and Seismic Properties. Geophysical Research Letters, 27, 2761-2764. https://doi.org/10.1029/1999GL008468

[27] Hamma Ada, M. and Harouna, M. (2019) Diagenesis and Reservoir Quality Evolution of the Paleogene sokor1 Sandstones in the Agadem Block, Termit Basin, Eastern Niger. International Journal of Advanced Geosciences, 7, 147-159. https://doi.org/10.14419/ijag.v7i2.29562

[28] Dvorkin, J., Gutiérrez, M.A. and Nur, A. (2002) On the Universality of Diagenetic Trends. The Leading Edge, 21, 40-43. https://doi.org/10.1190/1.1445846

[29] Avseth, P. and Veggeland, T. (2015) Seismic Screening of Rock Stiffness and Fluid Softening Using Rock-Physics Attributes. Interpretation, 3, SAE85-SAE93.

https://doi.org/10.1190/INT-2015-0054.1 